But funding for ACTs is uncertain. In 2012, the AMFm subsidized about $60 \%$ of the world's total supply of the drugs. With an unusual approach - supplying most of the drugs through small, for-profit pharmacies, rather than public clinics - the programme got more ACTs into circulation. But donors were not convinced that the drugs were reaching the neediest patients. In November 2012, the Global Fund announced that it would merge the AMFm into its broader malaria campaign (see Nature 491, 508; 2012). With so many demands on aid funding, some health experts worry that support for ACT distribution will falter.

Fabienne Jouberton, AMFm's senior officer for price negotiations, acknowledges that it will probably become much more difficult for A. annua growers and drug manufacturers to plan ahead. Rather than negotiating with a single body - the AMFm - they will have to assess demand separately in each individual country. "It's not optimal," she says.

\section{THE COST OF PROGRESS}

Prices of the malaria drug artemisinin vary wildly. Introduction of an efficient, microbially produced version could make things worse.

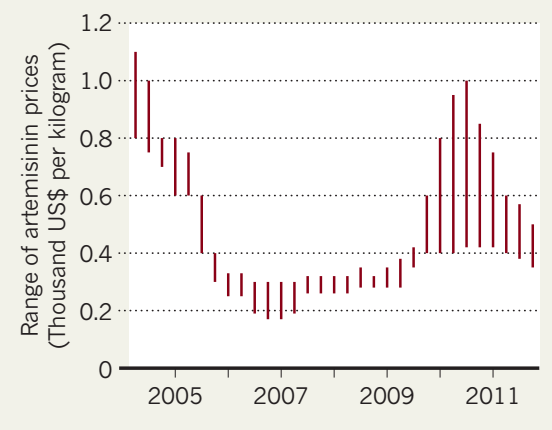

For now, artemisinin costs about US $\$ 400$ per kilogram, and the semi-synthetic version is unlikely to be much cheaper. But Sanofi announced at the Nairobi meeting that it plans to produce 60 tonnes of the compound in 2014, alarming A. annua growers and extractors, who said that the new supply could take more than one-third of their market. Sanofi and its partners are adamant that for the next several years, semi-synthetic artemisinin will be deployed only to smooth out market fluctuations, and will be sold at a 'no profit-no loss' price of \$350-400 that is unlikely to undercut other suppliers. The conference "almost felt like a price-fixing meeting", says Keasling wryly.

$\mathrm{He}$ is convinced that, eventually, the price could be lowered by making the fermentation process more efficient. Fitful funding is all the more reason to provide cheaper ACTs, adds Keasling, who would like all such drugs to be made using the semi-synthetic process. But he agrees that gradual introduction is necessary to avoid driving conventional producers out of business - at least "until we have enough installed capacity to take over the entire world supply".

PUBLISHING

\title{
Company offers portable peer review
}

\section{Author-pays service cuts down on redundant reviews.}

\section{BY RICHARD VAN NOORDEN}

$\mathrm{R}$ esearchers waiting for their manuscript to emerge from multiple rounds of peer review as it bounces from journal to journal can easily get frustrated at the inefficiencies of the system. Soon they may have another option: paying for a fast, independent peer review that could travel with the paper from one journal to another.

The concept comes from a company called Rubriq. Charging authors an estimated US\$500-700 for its service, the firm plans to offer a standard-format anonymized review, and is currently testing its concept with publishers including Public Library of Science (PLoS), Karger, F1000Research and Wiley, as well as more than 500 reviewers. The company - owned by research software and services firm Research Square in Durham, North Carolina is one of a number of firms hoping to capture functions usually performed by publishers.

Rubriq co-founder Keith Collier is confident that there is a gap in the market. "Millions of hours are spent every year on redundant reviews," he says. Collier has experience: he was previously general manager of ScholarOne, a widely used peer-review service based in Charlottesville, Virginia, and owned by Thomson
Reuters. He estimates that around 50\% of articles are initially rejected. Every resubmission can lead to another round of peer review, delaying publication and costing time and money.

Recognizing the problem, journals are increasingly passing on their rejected papers with peer reviews attached; but such transfers tend to take place only within a publisher. Matthew Cockerill, managing director of BioMed Central (BMC) in London, says that BMC's Genome Biology accepts around 10\% of submitted papers, but passes on $40 \%$ of those it rejects to other BMC journals together with the peer reviews; of those, around $50 \%$ are published somewhere within the BMC group.

Publishers are trying to share reviews more broadly: both BMC and PLoS are now working with the open-access journal eLife to explore passing on peer reviews with rejected papers, Cockerill says. But an early effort to do so - an alliance of neuroscience journals that in 2008 agreed to accept manuscript reviews from one another - has met with limited success. Before the scheme, journal editors who were wedded to their own peer-review standards "seemed more likely to use one another's toothbrushes than their review formats", says Clifford Saper, a former co-chair of the consortium. Even today, only $1-2 \%$ of rejected papers within the group are shared with other journals, says John Maunsell, a current co-chair.

Collier is betting that journals will accept the standardized peer-review form it has created, which follows the example of a similar organization called Peerage of Science, based in Jyväskylä, Finland. That service has signed up a community of more than 1,100 scientists and has processed 67 manuscripts. Authors pay nothing. Instead, journals subscribe to the service and are charged up to $€ 400$ (US\$540) for each manuscript they accept (three have been published in this way so far). Scientists can also point other prospective publishers to the reviews of their papers.

Rubriq's emphasis is on speed. By paying peer reviewers $\$ 100$ each, it hopes to get reviews back within a week. That payment will not compensate a reviewer for his or her time (which economic analyses have estimated as worth on the order of $\$ 400$ per review) but it could start to professionalize what has historically been a voluntary role, Collier says. The payments are covered by Rubriq's fee to authors, which also covers the administrative burden of recruiting reviewers and assigning papers - an estimated \$200. Pete Binfield, publisher of PeerJ, which aims to cut the costs of publishing dramatically and which launched its first articles this week, says that \$200 is a fair cost, and thinks that those activities cost about the same at PeerJ. (Binfield is on Rubriq's advisory panel.)

Other publishers are taking a more radical approach to publishing models: from the European Molecular Biology Organization's open peer review, in which anonymous reports are made public, to F1000Research's strategy: publish first and peer review later. But Collier says that Rubriq aims "to be an independent validation service to streamline the publishing process; we're not trying to disrupt the industry". 